CHAPTER FIFTEEN

\section{The challenges and opportunities of introducing Design Culture in Jordan}

\author{
Danah Abdulla
}

\section{Introduction}

Design Culture may be an area of study that is establishing itself in institutions across Europe, but the Arab region has yet to introduce this field in design education. As designers have become concerned with notions of community and social practice - under names such as social design, "good" design, design activism, humanitarian design and others (referred to as social design moving forward) - the need for integrating Design Culture in design education becomes more important, particularly as discourse continues to be Eurocentric in scope. The Global South remains non-existent and invisible within this discourse, and designers lack any professional representation for their field.

This chapter attempts to propose what the introduction of Design Culture would entail and its possibilities. It argues that introducing this field into Jordanian design education has the potential to shift from an outwardfacing focus and the wholesale imports of outside models, to generating location-specific and tailored knowledge and practice. Furthermore, the placement of design programmes in universities (as the independent art and design college does not exist in the country) presents an invitation for inter/ multi/transdisciplinary engagement and dialogue with other disciplines.

In this chapter, I begin to sketch out the possible content of this programme by first providing a brief overview on Jordan and Amman, the education system and the evolution of design in the country. While creating new knowledge on design culture in the country, Design Culture could provide room for Jordan, and the Arab region, to contribute to local, regional and international design discourse. The findings I draw on are from my $\mathrm{PhD}$ research on design education in Jordan, where I conducted twentyfive interviews, three focus groups and two workshops with designers, students and educators from Jordan. In this chapter, I refer to both Design Culture (upper case) as the academic. field defined as the 'stud[y] of the interrelationships between design artefacts, in all their manifestations, the work of designers, design production (including marketing, advertising and distribution), mediation and their consumption'; and to design culture (lower case) in a descriptive way: 'the circumstances in which design is developed, circulated and used' (Julier 2015, no pagination). Therefore, design culture is something that is all around and what designers do: a process and practice informed by context and milieu, an attitude, as agency and as a pervasive but differentiated value (Julier 2014). Design Culture/ design culture provides an understanding into the interconnections between humans and things, and recognizes design as being everywhere and affecting everyone (Charman 2013).

\section{Amman, design and design education}

Relative to its neighbours, Jordan's capital city Amman is a new city and possesses one of the region's most heterogeneous societies. The city's growth is linked to the region's geo-political and political circumstances (Nortcliff et al. 2009), and historically it is known as a 'refuge city' as it 'has experienced...a succession of migrations' which has 'shaped the structure of [the country's] social and political landscape' (Hinchcliffe and Beverley 2009: 22). Jordan's most unique quality lies in the fact that over half of the population is composed of people 'from outside its own borders and a people who are still struggling for self-determination and independence' (Hinchcliffe and Beverley 2009: 99). However, this complexity contributes to how Amman has difficulty defining its identity.

Amman is described as a city in a permanent state of 'temporariness, a metropolis on the cusp of emerging' (Innab 2016: 119), exasperated by the communities that settled in Amman where the city was meant as a transit stop, but for most it ended up being their final destination. The subsequent generations of the communities that have settled 'continue to look in two directions at once: toward home/homeland and toward a preferred temporary destination of a "second home" (Shami 2007: 215). This could explain why most of the city's inhabitants have difficulty in identifying as Ammani (from Amman), and see it as a temporary 'welcome mat'

Amman is a starkly divided city, and a person's class can be determined by the neighbourhood they live in. Citizens of the East seldom interact 
with those from the West - and many residents from East Amman feel as though the city no longer has space for them. The segregated space persists within the university. As Nasser Eddin explains in her experience at the University of Jordan, departments are labelled based on the lifestyles of the students: 'students of education, social sciences, Islamic law and humanities were labelled as "low class", conservative, and "backward". On the other hand, people from the Business School, the Faculty of Arts and Design and Departments of Engineering and Medicine were labelled as "high class", “open”, and “immoral”.' (2011:2).

The segregation is evident between public and private universities. Public institutions remain more competitive, and private institutions are largely profit-driven where tuition fees are the main source of income and cater to students with low qualifications who were unable to secure seats in public universities (Kanaan, Al-Salamat and Hanania 2009). The model of profitdriven institutions 'threatens to exacerbate one of the major deficiencies in Arab education, that is, selective exclusion for the rich and powerful in good quality education' (Fergany 2009: 45), further fuelled by limited availability of student loans and financial aid to many low-income students (Sabry 2009; United Nations Development programme and Mohammed bin Rashid Al Maktoum Foundation 2014). However, a focus on profitability - attributed to mounting demand - has led public institutions to offer spaces to students who were not admitted to their desired programmes due to an insufficient GPA through parallel programmes where students are charged higher fees (Chapman 2011, Kanaan, Al-Salamat and Hanania 2009).

Universities in Jordan are maintained by the Ministry of Higher Education and Scientific Research (MoHESR). The beginnings of design education in Jordan date back to 1980 when Yarmouk University launched a minor within fine arts. In 2001, design was granted a department within the Faculty of Fine Arts. The 1990s and early 2000s saw the establishment of more design programmes in public and private universities. Across Jordan, there are fourteen universities that teach design at the undergraduate level only, offering programmes in graphic, interior, industrial, and fashion design, design and visual communication, and design for cinema, TV and theatre. The quality of these fluctuates, as establishing design programmes have been a way to capitalize on demand and increase the profits of the university. Alongside these universities, twenty-two community colleges offer two-year diplomas mostly in graphic design (Abu Awad 2012). Unlike global trends where traditional demarcations of disciplines have started to recede (Julier 2014), separations of graphic, interior, product and fashion remain fully in place in education, and diminish slightly within practice mostly in independent and grassroots initiatives over studios and agencies. Design education in Jordan is focused on teaching technical skills rather than formalized knowledge and critical enquiry.

However, design continues to struggle to be recognized as a professionalized practice and to differentiate itself from trades like printing, despite the number of universities and community colleges teaching design and the establishment of dedicated design studios and agencies. This could be attributed to the absence of a professional association representing designers in Jordan and regionally who are 'dedicated to the promotion of various aspects of design and the systematizing or safeguarding of its practice' (Julier 2014: 51). Representation is an issue within the entire Arab region where only two design associations claim to represent designers region-wide: the Lebanese Graphic Design Syndicate (est. 1976) and AIGA Middle East (est. 2013). These are both based in Beirut but have contributed very little to design in Lebanon or regionally. Moreover, the international affiliation to the American AIGA, and the use of English in all its communication materials is problematic. It piggy backs on a brand and excludes designers working in Arabic. Furthermore, the use of the term Middle East encompasses countries like Turkey and Iran, countries with different histories, which speak different languages, and which have more established design histories and cultures with representation.

Within education, design's struggle can be attributed to the admission requirements imposed by the MoHESR. Admission to universities in Jordan are based on the results of the matriculation exam (tawjihi). This controversial exam, based on memorization, dictates the choices and future of thousands of students looking to apply to university every year. Design sits at the bottom of the academic hierarchy alongside fine arts and Islamic studies. Therefore, students with low GPA scores $155 \%-60 \%$ for private institutions, $65 \%-70 \%$ for public institutions) look to design. Based on findings from my $\mathrm{PhD}$ research, other reasons for choosing design are:

1 Design is considered an easy thing to study

2 Guarantees a job

3 Luxury of having a degree in art or design increases social standing

Students enter design without knowing what it is, further hindered by a lack of information on career options prior to applying for university. Therefore, admission requirements allow anyone to be accepted into design, branding design and design students as the rejects, and educators are faced with obstacles teaching these students. While some universities require applicants to sit through a drawing exam, often this is for appearances, and they are left with little choice but to accept anyone who applies. At most institutions, a portfolio of work is not a requirement for applicants.

Privatization of education has increased the number of universities teaching design as it is seen to be lucrative. However, these programmes generally focus on technical software skills. The MoHESR treats design as any other discipline, imposing the same admission requirements as any other discipline, and have similar research expectations from faculty. The departments remain peripheral, generating little to no knowledge for local, regional or international output. 
In the sections that follow, I outline a few challenges to design education in Jordan, and what this entails for the establishment of Design Culture programme, and attempt to lay out possible strategies for this programme.

\section{Centre/Periphery and the Westernized university}

According to Altbach (2006: 124-5), globalization has increased the dominant system of centre and periphery when it comes to the university. Powerful universities and academic systems - the centres - 'dominat[e] the production and distribution of knowledge' and 'the peripheries have tended to be dependent on them'. Peripheries also have their own regional centres, but no institution plays the 'centre' role in design regionally. Therefore, institutions and design students look to art and design colleges located in Western countries as models. Pushing Altbach's idea further, universities in Jordan are best described as Westernized universities - an institution that can be found anywhere globally, and features the same curriculum, the same authors and disciplinary divisions as any university in the West (Grosfoguel 2013).

The Westernized university - which most if not all design programmes fall under - promote or diffuse Eurocentric knowledge to produce Westernized elites in the so-called non-West that act as intermediaries between the West and the so-called non-West. Within Westernized universities, the canon of thought in all disciplines is composed of works of males from five Western countries (USA, Italy, Germany, England and France), and these structures have become 'commonsensical' (Grosfoguel 2013: 87). Knowledge is abstract from lived realities and histories. Furthermore, design programmes tend to focus on preparing students only within their specialized areas. Programmes, then, are resistant to change, where theory classes are limited, remaining within the art and design context, and students engage in no research or writing. Design education, as it currently stands, does not encourage alternative ways of thinking about design and designing. Design has no influence on other departments, rarely working with architecture or fine arts, even though they are often housed within the same department, contributing to its peripheral status within institutions themselves. The structure of the Westernized university is largely the reason for this. While we see more emphasis on design moving away from being discipline specific in Western institutions, as Anne-Marie Willis argues, higher education is highly instrumentalized, and 'theory is taught so it can be "applied" to design tasks', where 'discipline-specific design educators promp[t] defensive postures on the need to avoid of over-thinking, analysis-paralysis, and the like' (2015: 71). Theory and deeper investigation get relegated to the background in favour of outputs such as objects, websites, awareness campaigns or apps.
She argues that this enables design educators to 'feel secure because they are still turning out Graphic or Product or Interaction Designers, their disciplines remain intact and their jobs secure' (Willis 2015: 71).

The issue can also be attributed to the absence of serious research budgets, which forces universities and public research organizations to rely on foreign funding from foundations and UN institutions (Hanafi and Arvanitis 2016). The largest donors are the EU, followed by the USA, Japan and countries from the Arab Gulf - all of which are likely to have political conditions. Moreover, authoritarianism and an absence of academic freedom has contributed to the huge percentage of brain drain the region is faced with (Hanafi and Arvanitis 2016). Foreign funding often contributes to design projects centred around identity and heritage, which we now turn to.

\section{Cultural identity and marginalization}

The automatic assumption of the term design culture is that it relates to cultural identity. While the definition encompasses this, it is only one aspect of the study of Design Culture. Despite the progress that the field of design claims to have made in the integration of other discourses, this is merely decorative. Design from the Global South is constantly evaluated against Western design, stripped down to stereotypes, misunderstood and taken out of context, and the Global South often look to these design centres for models, without necessarily understanding the consequence of blindly borrowing its methods.

The design world, as Tony Fry claims, 'puts all peoples in [the] position [of marginality] - other than those who populate the few nations at the center of the rise of metropolitan capitalism' (1989: 17). Universal design attempts to universalize the experience of Western countries and its people - as if these are representative of the world - but these 'singular universal dreams of design worlds (modern "lifestyle") contradict, and certainly do not unify, great unevenness, difference, and ideological division' (Fry 1989: 24). These ideas, disguised as universal then travel to Westernized universities, who are reliant on knowledge produced elsewhere. It is clearly demonstrated in the divisions of classes where Westernized universities located in Arab countries have classes such as Islamic Art and History of Art, History of Modern and Contemporary Art, Typography (Latin) and Arabic typography. As Sami Zubaida reminds us, "when it comes to "Muslim culture" the unit becomes even more indeterminate, not only because of the multiplicity of nationalities and ethnicities, but also the varieties of identification of the region itself, and its adaptations to ideologies, generations, and styles of life.' (2011: 9-10).

Is Arabic or Islamic so alien that it requires its own special study even among the people who are Arabs and Muslims themselves? These divisions emphasize difference and assume that Arab or Islamic culture is lower on the 
hierarchical scale than Western culture, considered modern and contemporary. The Islamic and Arabic descriptor demonstrates the power of design's universal language. Universal is Latin, rendering everything else as non-Latin because it is not part of the canon, and implies a hierarchy (Pater 2016).

A more recent example that ignores realities is the rise of the social design movement. Social design practices are finding their way in the Arab region, where largely middle-class design students are looking to serve the needs of poor communities composed of people with very different backgrounds from their own, or designing for refugees. Moreover, some regional initiatives are referring to such refugee movement as if they are unique to this era and to the region, disregarding the region's history where mass migration has always played a role. Designers aim to provide a voice for the disenfranchised, using aid discourse, offering mere technological fixes than addressing the imperial histories and neo-liberal restructuring that underpin them (Johnson 2011), and maintaining dominance over the production of knowledge by using these communities for their school projects. These ideas travel to the Westernized university and are copy-pasted into the curriculum rather than through an awareness of the context and historicity of these ideas.

Design Culture provides a possible space to question this universality of design and the blind borrowing of ideas, practices and philosophies from elsewhere, or from a distant Arab/Islamic past. It can encourage designers to engage in a deeper, more immersive process of research, fieldwork and building trust with the community they work in rather than using hasty methods from human-centred design toolkits.

\section{Production, consumption and the designer}

Production, consumption and the designer inform each other, rather than working in isolation. In Jordan, the issue of bypassing the designer - that is, not understanding the concept of the designer or the value of design - leads to these being viewed as isolated. The study of design culture can help establish design's value to society and attribute a value to design. For example, the process of production, consumption and the designer, and how these inform each other discussed by Julier (2014), serves an important purpose in a country where designers are constantly bypassed, and the differences between the production person and the designer are not understood. It would establish what it means to be a designer, as opposed to the common perceptions designers are continuously faced with such as:

$\otimes$ Design as software

ه Design as aesthetic exercise

$\bowtie$ Design as crafts
The first is the difficulty design has faced in its professionalization, whereas the second is partly attributed to studios and agencies dismissing design's critical thinking and ideation aspect in favour of aesthetics. The third is an interesting point of study in Jordan. Whereas some countries in the Arab region have a strong history of crafts, Jordan does not. However, this is changing due to recent political circumstances, but crafts remain captive to heritage (turath) and tradition, catered to tourists rather than collaborating with designers on developing new methods and generating new knowledge.

Design Culture can present a new way of looking at craft traditions locally and regionally, and how these can feed knowledge into design, as well as empower both designers and craftspeople to engage with each other. There are particularities associated with a lack of machinery in the production, where designers can begin to understand the local tools and knowledge and how this feeds design, and begin to work with craftspeople on improving the work from a functional perspective by utilizing advances in material technology. ${ }^{1}$

Furthermore, Design Culture - where local and regional design history has a presence - focusing not simply on pioneers and objects but 'on the shifting roles of design today including the impact of new technologies, production methods, and lifestyle, i.e. design beyond products' (Julier 2014: 59) can prevent design from falling into the authenticity trap. Unfortunately, local design dialect with designers outside and inside the region, aside from Arabic typography and calligraphy, is dripping with stereotypes. Arab design is only Arab if it contains veils, camels, Arabesque typefaces, calligraphy, geometrical patterns, and rich sheikhs. This Orientalist Islamic identity associated with the region presents itself as authentic although it exists 'more in the imagination ... than in lived experience' (Shami 2007: 210). An example is a new-found interest in crafts and cultural heritage, heavily emphasized at Amman Design Week 2016. Example of this include the workshop Designing Contemporary Heritage with Studio Mieke Meijer (sponsored by the Dutch embassy), and the Raghadan tourist terminal, which was transformed into a crafts district to highlight the craftspeople as pioneers of design and making in Jordan, a largely invented tradition.

Furthermore, nostalgia has become an it trend in the work of Arab designers, where the work of Lebanese designer Rana Salam, which uses imagery from Arab film posters and pop culture icons from the 1940s to the 1960 s, has been copied to the point of predictability. The establishment of archiving foundations, and heritage tourism projects, has fuelled the nostalgia effect. This longing of nostalgia, as Zubaida reminds us, 'conveniently forgets its imperial context', where natives were often subjected to 'a rigorous system of exclusions [...] were inferiorized and despised' as in the case of Alexandria, Egypt (2011: 148). A social and cultural knowledge of one's own history helps form 'a self-reflective awareness' (Kassab 2010: 244).

Understanding how these domains of design work can help develop inter/multi/transdisciplinary projects within the academy - emphasizing the 
placement of design programmes within the universities and capitalizing on the other departments and their offerings (and vice versa). Furthermore, establishing a value to design enables design graduates to be hired to generate ideas and concepts, rather than as software 'monkeys'.

\section{Design culture as a way of understanding place}

A different discussion on identity is one related to the city, and Design Culture provides a good method for investigating this. Amman finds itself in competition with regional centres, which consist of some of 'the oldest still-inhabited urban centers ... aged capitals of powerful past empires, major religious sites, and centers of learning as well as notable colonial creations' (Shami 2007). Tourism and heritage initiatives display this clearly, where efforts were made to re-Orientalise the city by renovating downtown, remodelling shopfronts to add an Arabesque motif and erecting oriental fountains. However, the focus of Jordan's tourism campaign is Petra and biblical site, not Amman; and it remains a small stop on the way to these other destinations (see Jacobs 2010 for further discussion).

Amman has a lot to live up to, and the city is not the prototype for urbanism as it defies generalizations of how cities form historically and morphologically (Shami 2007). This is due to the 'fast and often arbitrary solutions that caused confusion in the city structure ... exacerbated by later efforts at remediation of such confusion' (Innab 2016: 119) caused by the influx of refugees. Shami concludes that 'the historical contingency that is Amman, therefore, has to be understood in a particular context of economy, state building, and cultural production' (2007: 230). For design, this statement is crucial: by understanding these contexts, can design help construct an identity for the city? Understand its formation and future? Due to design culture's unfixed nature, where 'it embraces a complex matrix of human activities, perceptions and articulations ... [a] [c]areful analysis of its visual, material, spatial and textual manifestations provides routes into this complexity' (Julier 2014: 5). The introduction of Design Culture grounded in the local and regional context can help tackle these questions and provide answers to them.

The possibility found in design culture is in providing agency to designers to take a role in establishing what happens to their city, rather than being allocated to the state. Residents are often marginalized from the city making process (al-Asad 2016), and design culture provides one way of changing this. Therefore, a programme focused on design culture must have as a primary aim the production of research, creating 'linkages between socially different worlds: different social classes, different locations, different places, different interests and different objects' (Hanafi and Arvanitis 2016: 14)

\section{Publishing}

Both Jordan and the Arab region lack publications devoted to solely to design. Currently, there are two publications dedicated to design: the monthly TrendDesign (based in Amman) is focused more on providing an international perspective and sound-bite type articles, and Journal Safar, an annual publication revolving around graphic design that is produced by Studio Safar in Beirut. Despite hundreds of publishing houses located in Jordan, publishers have contributed little to nothing to design titles. Books related to design in the region are published abroad, either by established publishers such as Gestalten, or by independent publishers based in Europe such as Khatt. What is particularly interesting is that not one Arab country 'enjoys a free press, and yet the Arab world probably has a more thriving print media than any other region in the world' (Hammond 2007: 237). Furthermore, and despite this fact, academic publishing is limited, as culture is considered sacred, since the many cultural productions that evolved 'in the colonial and postcolonial eras ... were developing under state patronage' (Ayish 2012: 83). This led to the majority of Arab intellectuals to 'evolv[e] their critical cultural perspectives outside state-patronised institutions, often in the bookshop and in independent intellectual centres' (ibid).

Whereas designers outside of educational institutions have contributed more to the discipline than those within - one initiative is the launch of Amman Design Week (ADW) in 2016 as an annual event described as 'a forum for learning, exchange and collaboration' seeking to empower designers and establish Amman as a hub regionally (Amman Design Week 2017) - there remains a large void in design writing and publishing. While $\mathrm{ADW}$ is a new venture, we cannot yet measure the impact it has on design culture. However, it provides one space for students, educators and designers to seek content from Jordan, as the lack of local material forces them to look for content written elsewhere, as these become the only publications available (Blankenship 2005), and while information through websites and videos has increased access to content, these are focused on software training videos or looking at portfolios and visual material. Publications provide a deeper alternative to these.

\section{What can Design Culture do?}

Introducing Design Culture within Jordanian design education presents great opportunities for the growth of design culture both locally and regionally. It could provide a platform for debate, a space for original and innovative thinking in design, critical historicization and grounding thought with lived and real experiences. Breaking the barriers between departments in universities to develop inter/multi/transdisciplinary engagement between 


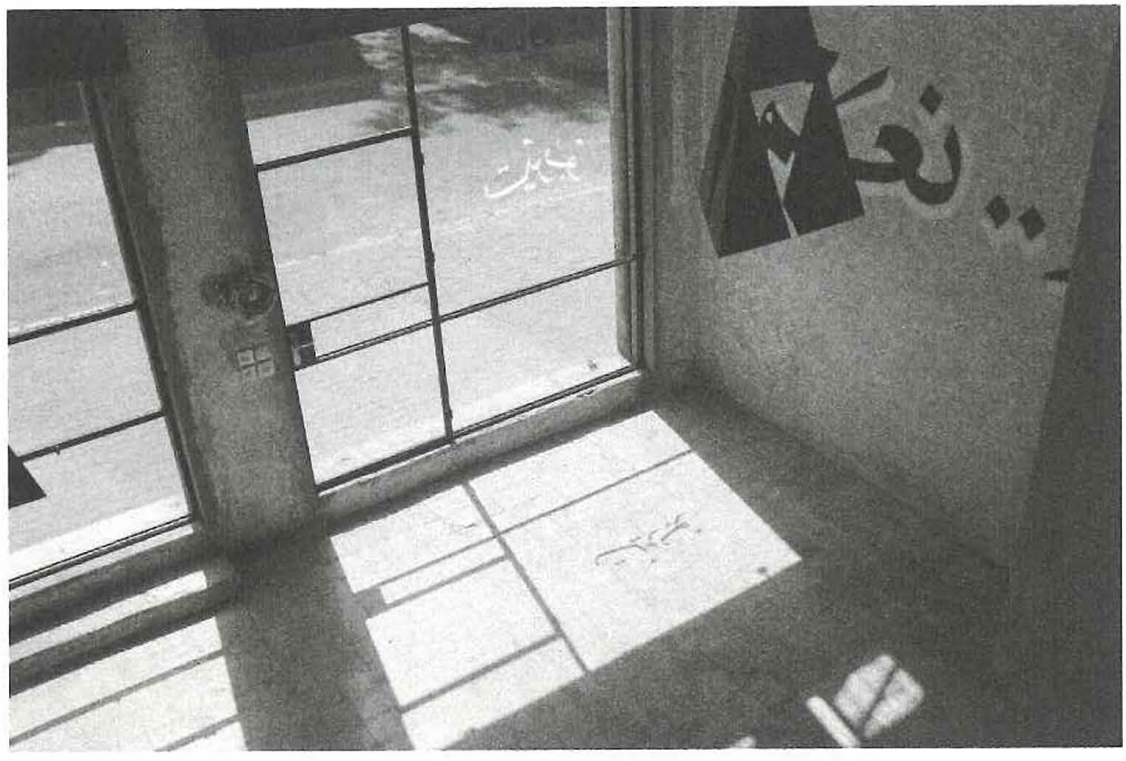

FIGURE 15.1 Studio Turbo in downtown Amman. Photography by Turbo (Mothanna Hussein and Saeed Abu Jaber). Image courtesy of Turbo.

disciplines could allow designers to engage in crucial theoretical grounding as design moves into more social practices and where designers prioritize knowledge creation by emphasizing research, criticism and writing. Looking at design from a local and regional context makes both education and practice more relevant to place and milieu as design begins to think of an epistemic pluriversality rather than a universal set of design solutions. By 'tak[ing] seriously the critical thinking of the epistemic traditions of the Global South', and shifting the direction of 'institutions appropriated by Eurocentred modernity' (Grosfoguel 2013: 88), it can help designers understand their history critically, and contribute to local, regional and international design discourse rather than attempting to play a game of catch up.

Design Culture can provide designers with the tools to become knowledgeable leaders that can help combat the ambivalent attitude designers have towards authority by granting them agency and establishing platforms that work towards promoting and establishing a value to design. Beginning to tackle these issues can promote a stronger professional identity for designers in the country, and to produce new knowledges in the field.

\section{Note}

1 French designer Christophe Pillet provides insight on this in 'Acclaimed: International Designers on Egyptian Design' by Karim Sultan in Kalimat
Magazine, Issue 04, pp. 118-121, http://www.kalimatmagazine.com/issue-04winter-2012.

\section{References}

Abu Awad, E. (2012), Identification of Competencies for Sign Designers in Jordan, $\mathrm{PhD}$. Coventry University.

Altbach, P. G. (2006), 'Globalization and the University: Realities in an Unequal World', in J. J. F. Forest and P. Altbach (eds) International Handbook of Higher education: Part One: Global Themes and Contemporary challenges, Dordrecht: Springer, 121-39.

Amman Design Week (2017), About Amman Design Week, Amman Design Week, Available at: https:/www.facebook.com/pg/ammandesignweek/ about/?ref=page_inter (Accessed 4 March 2017).

al-Asad, M. (2016), 'Teaching a Course on the Contemporary Arab City...for 5,700 People', in The Arab City: Architecture and Representation. New York Columbia University Press, 51-4.

Ayish, M. (2012), 'Cultural Studies in Arab World Academic Communication Programmes: the Battle for Survival', in T. Sabry (ed.) Arab Cultural Studies: Mapping the fields, New York, NY: I.B. Tauris, 79-100.

Blankenship, S. (2005), 'Outside the Center: Defining Who We Are', Design Issues, 21(1): 24-41.

Chapman, R. (2011), 'Jordan Fiscal Reform Project II: Education Public Expenditures Working Paper', Jordan Fiscal Reform Project II: Education Public Expenditures Working Paper. Available at: http://www.frp2.org/english/ Portals/0/PDFs/Mezzo-Fiscal.

Charman, H. (2013), 'Critical about Design', in N. Addison and L. Burgess (eds), Debates in Art and design education, Abingdon, Oxon: Routledge, 121-37.

Fergany, N. (2009), 'Education Reform Can Empower Youth in Arab Countries and Help Build Human Development', Youth and Mediterranean Challenges: Ouaderns de la Mediterrània 11(11): 43-50.

Fry, T. (1989), 'A Geography of Power: Design History and Marginality', Design Issues, 6(1): 15-30.

Grosfoguel, R. (2013), 'The Structure of Knowledge in Westernized Universities: Epistemic Racism/Sexism and the Four Genocides/Epistemicides of the Long 16th Century', Human Architecture: Journal of the Sociology of SelfKnowledge, 11(1): 73-90.

Hammond, A. (2007), Popular Culture in the Arab World: Arts, Politics, and the Media, Cairo: American University in Cairo Press.

Hanafi, S. and Arvanitis, R. (2016), Knowledge Production in the Arab World: The impossible promise, Abingdon, Oxon: Routledge.

Hinchcliffe, P. and Beverley, M.-E. (2009), Jordan: A Hashemite Legacy Contemporary Middle East. Second. Abingdon, Oxon: Routledge.

Innab, S. (2016), 'Reading the Modern Narrative of Amman', in The Arab City: Architecture and Representation, New York: Columbia University Press, 118-35. 
Jacobs, J. (2010), 'Re-branding the Levant: Contested Heritage and Colonial Modernities in Amman and Damascus', Journal of Tourism and Cultural Change, 8(4): 316-26.

Johnson, C. G. (2011), 'The Urban Precariat, Neoliberalization, and the Soft Power of Humanitarian Design', 27(3-4): 445-75.

Julier, G. (2014), The Culture of Design. 3rd edn. London: Sage.

Julier, G. (2015), What is Design Culture?, DesignCulture.info. Available at: http:// www.designculture.info/main/descultintro.htm (Accessed: 10 May 2015).

Kanaan, T., Al-Salamat, M. and Hanania, M. (2009), 'Financing Higher Education in Jordan', Amman.

Kassab, E. (2010), Contemporary Arab Thought: Cultural Critique in Comparative Perspective, New York: Columbia University Press.

Nasser Eddin, N. (2011), The Intersectionality of Class and Gender: Women's Economic Activities in East and West Amman. PhD. University of Warwick. Available at: http://go.warwick.ac.uk/wrap/54468.

Nortcliff, S. et al. (2009), “Ever-growing Amman”, Jordan: Urban Expansion, Social Polarisation and Contemporary Urban Planning Issues', Habitat International, 33(1): 81-92.

Pater, R. (2016), The Politics of Design, Amsterdam: BIS Publishers.

Sabry, M. (2009), 'Funding Policy and Higher Education in Arab Countries' Comparative \& International Higher Education, (1): 11-12.

Shami, S. (2007), 'Amman is not a City': Middle Eastern Cities in Question', in A. Cinar and T. Bender (eds), Urban Imaginaries: Locating the Modern City, Minneapolis: University of Minnesota Press, 208-35.

United Nations Development programme and Mohammed bin Rashid Al Maktoum Foundation (2014), Arab Knouledge Report 2014 Youth and Localisation of Knowledge. Dubai: United Nations Development Programme and Mohammed bin Rashid Al Maktoum Foundation. Available at: http://www. arabstates.undp.org/content/rbas/en/home/library/huma_development/arabknowledge-report-20140/.

Willis, A.-M. (2015), 'Transition Design: The Need to Refuse Discipline and Transcend Instrumentalism', Design Philosophy Papers, 13(1): 69-74.

Zubaida, S. (2011), Beyond Islam: A New Understanding of the Middle East, London: I.B. Tauris.

\section{Epilogue:}

\section{Towards design culture as practice}

\section{Guy Julier and Anders V. Munch}

The contributions of this book demonstrate the complex configurations of design culture by approaching very different layers and topics through various disciplinary and multi and interdisciplinary approaches. This underlines the consideration in our introduction on Design Culture ${ }^{1}$ as a multi and interdisciplinary field of enquiry. The investigations follow the changing nature and constant development of its objects, these being contemporary design cultures. They necessarily stray across disciplinary demarcations, therefore.

The sections have explored how Design Culture has developed as an emergent discipline to understand current cultural changes and challenges; how design is being positioned between market and society; how designers have to position themselves ideologically and professionally as many other actors now promote their services as design; and how design culture unfolds in and across various places, spaces and geographies. It therefore stands that these themes invite a range of disciplinary pathways that were followed both in discreet and amalgamated ways.

All these fuzzy borders, tensions, logics and ideals mean that the many actors in and observers of design culture have to keep manoeuvring in this contested field. They also have to develop overall understandings of its cultural interrelations and compositions.

Beyond its academic investigations and interpretations, the deployment of the term 'design culture' also becomes a tool of professional practice or civic aspiration. This describes a shared set of understandings of and enthusiasms for design at the centre of an organization, firm, place or other assemblage of interests. Building a design culture may involve a set of consciously 